\title{
A Key to Willows Exploration and Enjoyment
}

By HUGH McLAUGHLIN, Lewvan, Sask.

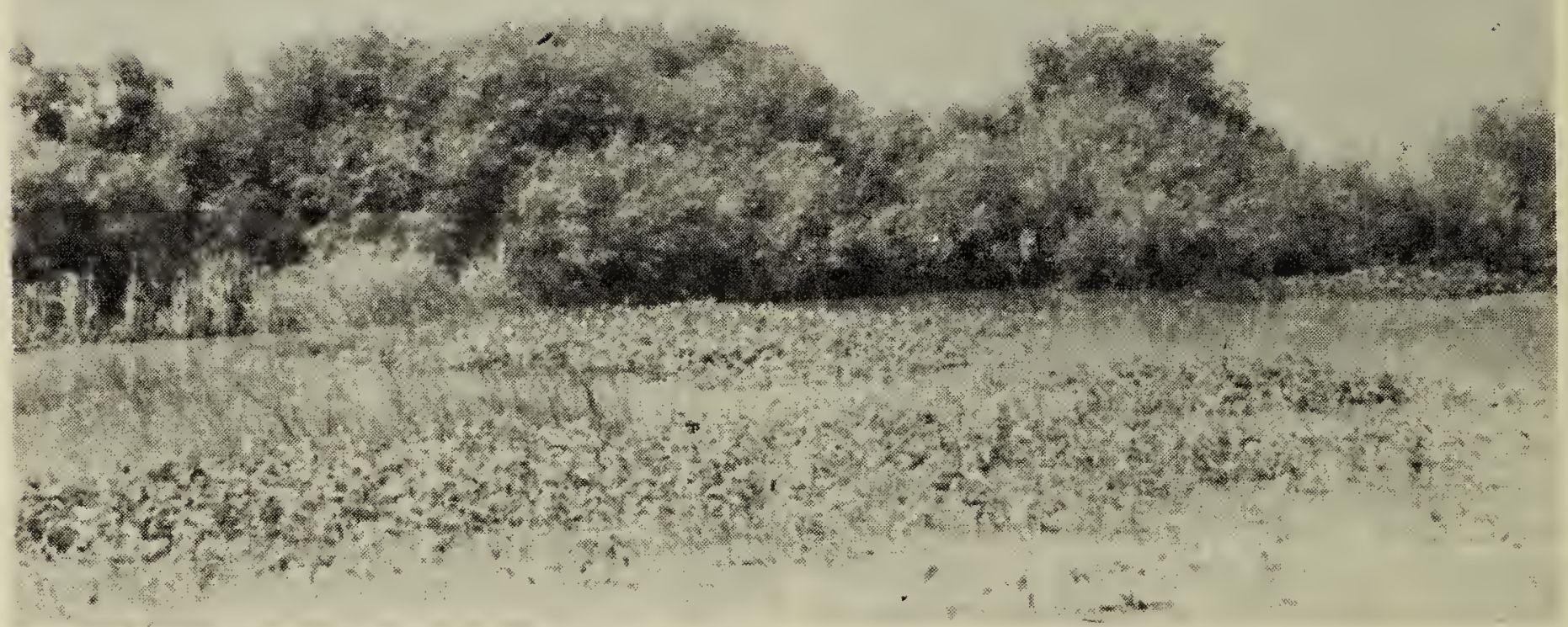

Sometimes the key to the door is handed to us and we do not use it, but in this case I am speaking of the "Key to Willow and Poplars" printed in the Blue Jay and contributed by A. J. Breitung. It had been lcoked at, but not explored until either the key or the willows, I don't recall which, inspired an exploratory inquiry that gave a new field of interest and enjoyment.

I read of places where the land is being cleared and over-cleared of trees and native vegetation, and older people recall the growth of former years. On the prairies the process has been to an extent reversed. Quoting Professor John Macoun's comment on the Souris plains in 1870's "no shrub over six inches high exists, due no doubt to the numerous fires which pass over the region." Old photographs of areas now well tread around sloughs and draws show people, beards and wagon wheels against a background of stark naked prairie. This is particularly so in the area east from Weyburn to the Moose Mountains.
The gumbo clay comprising the Regina plains is not such a favourable environment and most species of trees will not compete with native vegetation or even grow on cultivated scil without extensive care. However the plentiful moisture of the last few years has encouraged quite an encrcachment, and nearly every dugcut and low lying roadside ditch carries a complimentary fringe of the lowly willow. Just what this encroachment comprised of, or its extent I did not realize until I began studying the Key to the Willows.

They are quite a challenge to separate and identify - a real cross word puzzle and it seems to be a gradual process before you can glance at a group along a roadside and recognize several species. It is as though out of a crowd of people - formerly a mere blur of strangers; you can now recognize friends and characters. After considerable comparisons, about seven species emerged - and also mingled were aspen, poplar and western cottonwood. Most of the local growth is immature, 
possibly five or six years old, so I decided to go to a point on the Souris creek where a grove of more mature trees has been gradually assuming proportion on the landscape. Thirty years ago there were only a few clumps trom which we occasionally sought kindling for a fire while skating and these almost disappeared during the dry cycle of the thirties.

I did not realize the extent of the growth until with sons Don and Grant, we made an exploratory trip down the creek by canoe. There were round mounds of growth six to eight leet high which I took to be Salix Potiolaris or Basket Willow-another very symetrical and heavier branched shrub with hoary leaves which I could only guess as Sage willow. Predominate was a thicket forming growth - Sanbar willow which rose to twenty feet high, and stole back from the creek banks to engage in commando tactics with the native grass, and even the wheat field. It would take over the scd and then other species of willow would take hold as undergrowth. Several credible Peach Leafed and Diamond willow stood out. The first mentioned with main trunk of twelve inches in diameter and the latter with several main trunks of six to eight inches in size. Somewhat similar growth, but a bit smaller in size was also the familiar Pussy willow. Western cottonwood also appeared in the growth.

The fact that a small prairie stream could be navigated by canoe in July could only mean a dam somewhere. And while not unexpected, it is still a novelty to come upon a beaver house on the south bank, and two hundred yards further downistream the skillful structure which held back the mile or so of water. Years ago the beaver was a remote animal as far away as the history of the Hudson Bay Company and encountered here only in books. I am grateful that the owner of the grove has tolerated this growth, as the scene is not a common one on the gumbo plains, and the presence of the beaver enhance the scene - also the water they have dammed up, makes a mecca for water fowl and muskrats.

I renewed an acquaintance through this excursion - found a delightful spot locally, and became very tree conscious. I could now see hundreds of willows growing among the weeds on the roadside where I never noticed them before. Until freeze-up in the fall, as many desirable plants as I could move, were transplanted along a somewhat barren stretch of creek bank - as they will not probably be tolerated along the roadside. I look forward to a grove closer at hand, with all the association of bird and animal life that trees will bring. It has been rewarding to study and tap another faucett of interest, and I am glad that I used the "Key."

Perhaps a little mundane - but still resourceful was the story given to me of the beaver on the Moose Jaw Creek, who set up housekeeping on a wheat field, and then proceeded to bury under water 15 to 20 stooks of grain, and even chewed out of way a corner fence post that impeded harvest. A somewhat embarrassed beaver must have been the one discovered in a small ditch of water in our local village. After a series of futile plunges in the muddy shallows, it was herded down the main street of a prairie village by an interested populace - with the famous paddle of a tail dragging in the dust. Being driven to a dugout it treated us to the sight of its clever manipulation of peeling bark from willow trees - as it sat and ate in plain sight 20 feet away. We feared and cared a bit for our struggling local spruce, poplar and other landscaping, but it weent on its way in a day or so.

\section{The Moss}

\section{By M. A. Welsh, Prince Albert}

In the December Issue Dr. Conard had an article on Moss. I have taken up the challenge which he presented therein and I can assure you that I have not regretted this. Dr. Conard has been very helpful in providing identification for me and I might say that I am slowly accumulating a nice small collection of Moss. Any person who is interested in Moss would be well advised to reread this article. His suggestion of compiling a check list is, I think, a very worthwhile undertaking. 